\title{
The World Practice of Development of Writing for Non-Literate Cultures
}

\author{
Aleksandra A. Sitnikova* \\ Siberian Federal University \\ 79 Svobodny, Krasnoyarsk, 660041, Russia
}

Received 04.09.2018, received in revised form 24.09.2018, accepted 05.10.2018

The article focuses on foreign scientific practices in the creation of orthographies for unwritten languages in order to find a high-quality and effective algorithm for the Enets writing approval and development. The review of modern foreign researches is dominated by the analysis of the publications issued by the scholars of SIL international, the most experienced and authoritative organization in this field. The first part of the article gives a description of the algorithm for the development of written languages for the indigenous peoples, the description being recognized as the most promising at the beginning of the $21^{\text {st }}$ century. It highlights the stages, principles and scientific attitudes, lists linguistic and non-linguistic challenges that arise in the course of the development of writing. The second part analyses specific cases of a) the SIL scholars' successful creation of writing for the Mexican languages, in particular, for the Mixtec language; b) unsuccessful attempts to create the writing for the people of Darma living in Nepal on the border with India. It is concluded that modern techniques in the field of orthographies can be used to create a written Enets language.

Keywords: orthography for unwritten languages, unwritten languages, a case study of the development of writing in the $21^{\text {st }}$ century, the Enets language.

The reported study was funded by the Krasnoyarsk Regional Fund of Science within the "Development of scientific and methodological support for a unique cultural heritage preservation for the Ket and Enets ethno-cultural groups of the indigenous peoples of the North, Siberia and the Far East living on the territory of the Krasnoyarsk Krai" research project.

Research area: culturology.

Citation: Sitnikova, A.A. (2018). The world practice of development of writing for non-literate cultures. J. Sib. Fed. Univ. Humanit. soc. sci., 11(10), 1635-1652. DOI: 10.17516/1997$1370-0325$

(c) Siberian Federal University. All rights reserved

* Corresponding author E-mail address: sem dobrianka@mail.ru

This work is licensed under a Creative Commons Attribution-NonCommercial 4.0 International License (CC BY-NC 4.0). 


\section{Introduction}

At the beginning of the $21^{\text {st }}$ century, development of writing for unwritten languages has become one of the main tasks of linguoculturology once again. After writing was created for most of widely spoken languages on earth (English, Chinese, Russian, a number of European languages, etc.) millenniums and centuries ago, at the beginning of the $20^{\text {th }}$ century, in different countries there arose a problem of all peoples' integration into global cultural processes, the peoples remaining on the economic, political and cultural periphery due to the lack of writing and, as a consequence, their illiteracy. Activation of the processes of writing development for such peoples in the early $20^{\text {th }}$ century is connected with the spread of the idea of universal literacy and the introduction of compulsory education as well as with a number of other factors (for example, in the 1920s, in America, the development of writing for the indigenous peoples was linked to the missionary spread of the biblical doctrine (W.C. Townsend's activities); in the USSR it was influenced by the political prospects to build an international communist regime, etc. Despite the fact that the work of the global scientific community to create writing for the indigenous peoples, which involves linguists, anthropologists, and cultural scientists, has been underway for a century, the scholars record that there are more than 7000 languages in the world today, and only a little more than 550 languages have their written versions. Moreover, unwritten languages are more vulnerable to extinction. "Ethnology. World languages" website provides significant static data on the number of endangered languages (as of 2018): in North America the number of such languages is 157, in Central America - 43, in South America - 137, in Europe 50, in Asia - 193, in Africa - 134, in Australia and the Pacific Islands - 205 (Simons, Fennig, 2018).

Whereas some scholars are skeptical towards the issue of the urgency of creating the written versions for all languages in the world in the light of the ideology imposition and dissemination and the mindset of the dominant cultures (e.g., Justin T. McBride (McBride, 2009)) or the authors of "The Tyranny of Writing. Ideologies of Written World" (Weth, Juffermans, 2018), most researchers agree that the written language is the most useful cultural invention for the following reasons:

- the population's literacy improvement - the native speakers get an opportunity to improve their economic, legal and cultural literacy;

- the increase of the level of people's ethno-cultural self-identification;

- with the advent of writing it becomes possible for the endangered languages to preserve cultural memory in the texts. 
Besides, UNESCO recognizes the possibility to state one's language as each community's basic right.

This article presents a study of modern foreign theory and practice of creating orthographies for unwritten languages in order to reveal the most effective and viable algorithms for the development and promotion of writing for the Enets endangered language of the Russian Federation (a three-letter international designation of the language is enh; the code is $8 \mathrm{~b}$; the language is on the verge of extinction: as per the 2010 data, 230 speakers which is less than $10 \%$ of the ethnic group speak this language).

The scope of the study relates to the need to coordinate modern scientific works on the development of the Enets language writing by the leading scholars of the Department of cultural studies at Siberian Federal University (N.P. Koptseva, V.I. Kirko, K.V. Reznikova, N.N. Pimenova, N.M. Leshchinskaia, E.A. Sertakova, Iu.S. Zamaraeva, N.N. Seredkina, A.A. Sitnikova, N.A. Sergeeva, et al. (Reznikova, Zamaraeva, Sergeeva, 2018)) with the world, foremost foreign, practices in this area.

\section{Research Methodology}

The methods of the research are:

1) analytical review of modern publications in leading scientific peer-reviewed journals on the issue of creating the orthographies for unwritten languages in order to identify an effective algorithm for such work;

2) analysis of real cases in the world practice of development of writing for unwritten languages in the $21^{\text {st }}$ century;

3) field researches of the scholars of the Department of cultural studies at the Siberian Federal University (V.I. Kirko, N.N. Pimenova, A.I. Fil'ko) in the village of Potapovo (Krasnoyarsk Krai, the Russian Federation), a settlement of the Enets' compact residence on the Bank of the Enisey river. The materials make it possible to coordinate the scientific work on creation of writing for the Enets with the world practice of scientific work in this sphere.

\section{Research}

\section{Literature review}

It is obvious that the history of creation of writing dates back to thousands of years ago. However, this study analyzes the current theoretical foundation, which the scholars base on in the $21^{\text {st }}$ century when creating new orthographies for the indigenous 
peoples' languages. Such fundamental theories were formulated in the $20^{\text {th }}$ century and get enriched by the scholars up to the present. These conceptions are usually interdisciplinary (Zamaraeva, Reznikova, Pimenova, 2017) and develop in line with visual anthropology (Koptseva, Yl'beykina, 2014), cultural anthropology (Libakova, Kolesnik, Sertakova, 2017; Reznikova et al., 2016), urban anthropology (Kistova et al., 2016; Sertakova, 2018), indigenous studies (Berezhnova, Pimenova, 2016; Koptseva, Kirko, 2014; Libakova, Sertakova, 2018; Pimenova, 2018), ethnic studies (Koptseva et al., 2016).

One of the world's largest organizations in the field of creating writing for unwritten languages is SIL (Summer Institute of Linguistics) initiated by W.C. Townsend (18961982), a Christian missionary linguist who believed that every small nation will better understand the biblical teaching if this teaching is written in their native language. First people, for whom W.C. Townsend developed the system of writing, were the Kaqchikel people in Guatemala (Townsend, 1961). In 1934, he began training other scholars who wanted to work with the languages of the indigenous peoples. The trainings were called "Summer Institute of Linguistics" and later turned into a large international organization. Today, the scholars are developing the systems of writing for the indigenous peoples in North America, Mexico, South America, Africa and a number of Asian countries, that is, almost all over the world. Thus, it is the analysis of the SIL scholars' developments that this article focuses on.

W.C. Townsend 's follower, his disciple, and the SIL President till 1979 was Kenneth L. Pike (1912-2000). He studied Mixtec languages in Mexico. He is the author of "Phonemics: a Technique for Reducing Languages to Writing" (Pike, 1947), a fundamental work in developing orthographies for unwritten languages. In his book, Pike identifies such problems of transformation of a phonetic language into a written language as the words division, letters for vowels and consonants, the language tonalities writing system, etc., having suggested the ideas that many scholars have been using until today.

William A. Smalley (1923-1997) is another American scholar whose works form the basis for the creation of writing for unwritten languages. His most important achievement in the field of applied linguistics is creation of Roman popular alphabet for the Miao/Hmong language, which is spoken by the Miao ethnic group living in Northern Vietnam, Thailand, China, and Laos. In his theoretical works Smalley suggests several basic principles for writing development. These principles became a sort of "axioms", a starting point for modern practices in the field of orthography development (Smalley, 
1964). They are formulated in a simple way and represent the following prerequisites: 1) maximum of motivation: it is necessary to develop orthography to be willingly used by people both on personal and state levels; 2) each sound of the language should correspond to one written sign; 3) orthography should be easy to study; 4) the written language should be as easy as possible to reproduce, including the case of reproduction when using modern printing devices; 5) the language should be easy to translate into the state/national language.

One of the first manual guidelines for the creation of written language for the indigenous peoples was one by S. Gudschinsky (Gudschinsky, 1973) who worked in SIL. Her methodology was termed as "Gudschinsky's method".

No less authoritative researcher is Joshua Fishman, an American founder of sociolinguistics whose works are referred to by the developers of writing. "Advances in the Creation and Revision of Writing Systems" (Fishman, 1977) is considered his most important work on this issue.

In the second half of the $20^{\text {th }}$ century, due to the fact that a considerable number of linguists acquire their practical experience - both successful and unsuccessful - in the field of the development of the systems of writing for unwritten languages, they publish articles with the analysis of real practices on the development of the systems of writing for unwritten languages in Guatemala, Mexico, Northern Africa, Latin America, Papua New Guinea, Canada, Thailand, the Philippines and other countries and regions of the world, paying attention not only to linguistic methods of writing development but also to numerous extra-linguistic factors. They also compile manuals and guidelines on how to organize the process of writing development. Among contemporary professionals in this field there are the names of Michael Cahill (Cahill, Karan, 2008), Elke Karan (Karan, 2006), Kate Snider (Snider, 2014), et al. All these authors belong to the SIL research group and published "Creating a Writing System for Unwritten Languages" (Cahill, Rice, 2014), a significant modern collection of scientific works on the issue.

Besides the American researchers, British scholars are actively involved in the process of designing the writing system for unwritten languages. In particular, at the University of Cambridge, there is a group of scholars engaged in documentation of endangered languages and cultures, Mary Jones, the editor of "Creating a writing system for endangered languages" (Jones, Mooney, 2017) being the head of the group.

Australian scholars are also involved in active development of the indigenous languages. This is especially so due to the fact that, according to the "Ethnology. Languages of the World" site, Australia has the largest number of endangered 
languages, the number being 205. MIROMAA. Aboriginal Language and Technology Centre can be mentioned as one of the Australian resources in this area.

\section{Modern algorithms of developing the systems of writing for unwritten languages}

Basing on modern publications, which were listed in the previous section, as well as on practice of field research and communication with the native speakers in the settlements of the Krasnoyarsk Krai indigenous peoples' residence - the Evenks, Nenets, Enets, Chulym people, Nganasans, Dolgans, Selkups and Kets, it is possible to describe an effective and viable algorithm for creating the system of writing for unwritten languages at the beginning of the $21^{\text {st }}$ century.

Development of writing for the indigenous minorities starts with answering the question about the purpose of writing development: who and how should benefit from this? who is the target audience most interested in the further use of writing? Modern scholars' answers to these questions are contradictory. Some scholars express a skeptical point of view, according to which the development of writing for the endangered languages is a nail-biting, as even if the development of writing is successful there will be no people able to use and, thus, revive it. Besides, socio-economic factors indicate that the indigenous peoples themselves are primarily interested in learning the language of the dominant culture or the languages of international communication (for example, English) as it will favour professional and financial well-being, yet, the study of the native language in this situation complicates the already difficult situation with getting the education. Moreover, the invention of writing for all the peoples is a costly affair. Finally, even in the case of the development of writing the number of real reasons for the use of writing in the native language in everyday life is extremely small. Yet, a vast majority of researchers consider the process of development of writing for the peoples having no written language to be a positive phenomenon, firstly, basing on the UNESCO basic thesis that it is the unconditional right of every people to have their own writing in their native language and arguing their position that the development of writing for the indigenous peoples makes getting education easier, increases the number of legally and economically literate people among the indigenous peoples, enhances the people's ethnic identity. All these ultimately increase the number of indigenous peoples, allowing them to integrate into the global world processes more easily while maintaining their own individuality. The scholars also note that there is nothing wrong with the fact that writing in the indigenous people's native language will not spread 
everywhere: it will become neither everyday nor administrative practices, but will be used only as the people's symbolic capital, a ritual use of language for the sake of raising ethnic consciousness. Finally, the development of a written language for the indigenous peoples will help to preserve full information about ethnic culture in the world space of the Internet and make the information about this culture available to future human generations.

The second important stage in the development of writing is the language integration into the state system of the country of the indigenous people's residence: the dominant language system the new writing will be built into, the surrounding languages the indigenous people will subsequently contact most actively, state mechanisms for regulating and registering the new writing that exist in this country, etc. It is correlation with this factor that the choice of the grammatical system of writing will depend on for the language to be easily translated into national languages later, the graphical representation of writing being selected from Latin, Arabic scripts, Cyrillic or Chinese characters, etc. Each country has its peculiar approaches and state systems regulating this issue: for example, in some African countries, the indigenous peoples prefer their written languages to be based on French whereas some African nations insist on Arabic type letters. Working with the indigenous languages of the peoples of Mexico for a long time, the scholars came to the conclusion that their writing must be built on the basis of Spanish, etc. There are lots of cases that take into account the history of the indigenous people. As for the Enets language, it is obvious that in the $21^{\text {st }}$ century its system of writing must be built on the basis of the Cyrillic alphabet. This is because, first of all, the Enets community is a part of the Russian Federation with Russian as its official language and all attempts of the Russian scholars of the $20^{\text {th }}$ century to Romanize the indigenous languages have failed. At the legal level, the possibility of adopting a new system of writing for the indigenous minorities in the Russian Federation is regulated by the Constitution.

Theoretical development of orthography is considered to be the next stage of writing development. At this stage, the group of scholars - linguists, anthropologists, cultural studies scholars - develops the writing project on the basis of theoretical knowledge about the language as well as on the basis of the analysis of the native speakers' language records, communication with the authoritative speakers. This work is carried out mainly by linguists, guided by the classical theory of linguistics and a number of modern rules for the development of writing. Many scholars refer to important points that should be considered in the course of development of writing in modern language 
situation. These are primarily the following ones: 1) it is desirable that one phoneme corresponds to one written sign; 2) when documenting the language in an audio form it is necessary to pay the speakers' attention to accurate pronunciation of words but not to rapid one so that the researchers could clearly and correctly fix the written form of the words; 3 ) it is important to find the right balance between a thorough phonetic recording of the language (so that each phoneme and tonality are reflected in the written version) and a simple written recording (for example, it is known that in the future it is easier to remember short words when learning a language, yet the principles of separating words from each other still need to be discussed with the native speakers); 4) when choosing the type it is necessary to be intended for existing fonts adapted for modern printing devices (for printing on a computer, mobile phones), so that when introducing writing into modern everyday life, which implies mandatory existence in the media space, it is not necessary to develop an additional interface (for example, graphic fonts, additional signs for the keyboard, etc.) since this greatly complicates the possibility of using the written language in the future. To develop writing based on the Latin alphabet there are convenient tools that help the linguists (the international phonetic alphabet or Unicode, for example). Other important linguistic laws on the development of writing are listed in the previously mentioned publications by K. Pike, W. Smalley, S. Gudschinsky and other researchers.

The field research follows the theoretical work on the development of orthography. It should take into account a significant number of external linguistic factors historical peculiar features of the indigenous people's life, socio-cultural contacts, prospects for the use of writing in everyday life and ritual practices, etc. At this stage, the researchers identify the target audience interested in the use of writing: is there a younger generation that would like to support the development of the native language and its revival? are there any prospects for the use of language in domestic routine (it is known that at the present stage the daily use of the language in the family is considered to be the most effective way to preserve the endangered language)? is there a need in creation of Internet services and mobile applications in the indigenous people's native language? are the indigenous people interested in learning their language at school and using it in getting education? Or, as is the case with some languages, the target audience is external researchers who study the culture of a given ethnic minority. Determination of the target audience for the written language entails the choice of the principles of its development - the scholars can focus either on a careful reflection of all the language nuances in writing or on making it easier for the use on modern computers and mobile 
applications, or on making it easier to be studied by the people not directly related to the language.

An important point in the writing development is to discuss all variants of writing, word division, and rules of reading with the native speakers (with as many native speakers as possible). The issue of choosing a dialect will also be very important for the native speakers. The world practice shows that the researchers hardly manage to approve a single version of the dialect on the basis of which orthography will be formed as when writing the native speakers from one village cannot agree with the adoption of the dialect of the same language used in another village. There is the world research practice when they develop as many variants of writing in the language as there are the dialects existing. Sometimes the researchers manage to approve the version of writing in the dialect which is spoken by the authoritative representatives of the indigenous people. Another point that may concern the native speakers is the choice of a graphic writing the consensus on which is not always possible to reach. In any case, the involvement of as many native speakers as possible in the process of writing is the key to the success of further acceptance of writing and its viability.

Finally, the final stage in the development of writing is its formal approval and adoption in accordance with the state regulations that exist in the country on the territory of which the indigenous people, for whom writing is developed, reside. It may be noted that since this procedure often involves the native speakers' voting the scholars often fail to achieve solidarity among the ethnic minority, and many new systems of writing freeze at the level of theoretical development without getting its real existence.

\section{Analysis of cases of development of writing for unwritten languages in the world practice}

As mentioned above, in modern scientific literature there are a significant number of publications on the development of writing for numerous indigenous minorities that did not previously have their written languages. In the context of the objectives of this research two cases will be dwelt upon. These are an example of successful development of writing and an unsuccessful attempt to develop it for the people of Darma valley on the borders of India and Nepal.

The first case is the analysis of the process of development of writing for the Mexican indigenous peoples, the Mixtec language, in particular, by the SIL scholars. 
A generalized description of this process is presented in Joseph P. Benton's paper published in 1999 (Benton, 1999).

It was Kenneth Lee Pike's work that serves the fundamental theoretical basis for the scholars, an example being his linguistic statement of the necessity to record carefully spoken words but not a fluent speech. Following his ideas, the researchers paid attention to a careful division of words when compiling the dictionaries. In questionable situations they asked the native speakers whether these words should be written separately or not. They were also guided by the rule of an easy way of learning and, thus, tried to separate too long words as the variant of their writing will be difficult to remember.

Apart from K.L. Pike's works the scholars based on William A. Smalley's rule of conformity of writing with the political situation. As a result it was decided that Mexican writing should be built on the basis of Spanish (it should be noted that the state institutions' earlier attempts to develop writing for these peoples were guided by the rules of classical linguistics, on the basis of which writing was solely designed with the focus on linguistic factors, thus, it did not take into account the correlation between Mexican and Spanish systems of writing, for example, the use of existing letters and grammatical rules of Spanish for writing in Mexican; as a result, this purely linguistic - project did not turn to be viable). The scholars also considered such Smalley's basic rules as the requirement for the maximum number of phonemes in writing. It was also stated that writing should be easy to learn, the language should be easy to translate into other languages (in this case, in Spanish), and the language should be easy to read.

In addition, in the course of its existence SIL has developed its important principles in the field of orthography development: orthography should be tested among the native speakers, accepted/registered at the national level, convenient for communication with the outside world.

There were three stages in development of writing: theoretical, practical (the native speakers' involvement in the discussion of orthography), the stage of official acceptance of orthography.

The scholars faced the following linguistic challenges in developing the system of writing: the writing system for the vowels, that for the consonants and tones, stress, division of words, affixes, and punctuation.

The main difficulty in working with the Mexican languages was that most languages are tone ones and some languages have 5 tone registers. Thus, it was necessary to 
choose a convenient form of the system of writing that would not contradict the Spanish language and would be easily reproduced on modern printing devices. For example, the Chinantec languages have five tone registers. It was agreed that the system of writing of the language would have numbers (from 1 to 5) to indicate the tone in the upper register after each word.

When working with the Zapotec languages it was necessary to introduce the additional symbols to distinguish vowels. In each case, the scholars tried to adapt to the Spanish keyboard.

SIL's another positive practice in working with the Mexican languages was that the colleagues working at the development of writing for different Mexican languages united their forces and suggested using mostly the same characters in the system of writing in different languages. In the future this considerably simplified the possibility of further communication between different Mexican peoples in their native languages. To this very day the scholars have studied different Mexican languages independently and separately, having no experience of uniting their efforts.

The members tested the orthography by trial and error. The scholars print some materials, distribute them among the native speakers, train them and see their reaction, correcting those moments that cause the greatest difficulties for the native speakers until all the errors are minimized.

Finally, several variants of orthography were developed in the 1990-ies. In 1997, these were the leaders of the Mixtec community who established the Mixtec Language Academy. They took the responsibility for the approval of the single best variant of the Mixtec language.

The second case is a description of an unsuccessful attempt to develop writing for the Dharma language (a Tibetan language spoken in Darchula District in Nepal) (Oko, 2018). In this case, the author - Ch.W. Oko - analyzes possible reasons for the failure to introduce writing.

Darchula District is one of the districts of Nepal (on the border of India and Nepal). As stated by the author the area speak the Rangboli language, which in its turn consists of three languages with different origins and different ethnic and cultural backgrounds. These are Dharma, Bangba, Byangkho (Darma (Darmiya, ISO 639-3 code drd); Bangba (Chaudangsi, ISO 639-3 code cdn); and Byangkho (Byansi, ISO 639-3 code bee)).

After the author came to the Darma valley to conduct her research on development of writing for the Rangboli language, the authoritative Bangba speakers advised her 
to focus on the language of Dharma as this language was spoken by a large part of the community who were poor and conservative-minded.

The native speakers of the Dharma language believed that the language had no grammar (as compared to Hindi), so writing would definitely fail. But Ch.W. Oko decided to make an attempt and, like all anthropologists and linguists, was engaged in recording language fragments, their deciphering together with the native speakers and subsequent theoretical understanding. Moreover, she joined the life of the community: together with her husband she was even adopted by the community members and, thus, they could observe the ceremony of child naming, funerals, and weddings. The scholar actively studied socio-cultural contexts: the rules of life in families, the rules of communication in mixed language families. She notes that most Dharma speakers were free to switch to Hindi and English to reach understanding with other villagers, who did not speak their language, as well as with the researchers. Moreover, the younger generation of the district was taught in Hindi or in English since fluency in these languages was associated with highly paid jobs. In the valley, English was considered the language of welfare. The indigenous language was spoken only by the older generation to use it as a secret code to discuss adult affairs. Yet, some members of the community had a desire to preserve the culture in its writing form in poems, proverbs, and descriptions of rituals.

Thus, Ch.W. Oko draws attention to the economic factor of failure to study the indigenous language.

The researcher describes an interesting fact. In the mid-1980s in the valley of Darma they established the committee on the development of writing for the language of Dharma, promising a significant amount (100 thousand rupees) to a human who will develop a writing system. Due to the fact that there were three developers who were always involved in the struggle for the reward, the General Assembly never accepted any writing, the reason always being two votes against one. The outsiders were not allowed to the competition. Thus, the researcher draws attention to an important problem: financial interests often become one of the main obstacles to writing development.

Ch.W. Oko points to the fact that constant close communication with the native speakers might become the key to the adoption of writing. Yet, a few people expressed a desire to communicate with the researcher on the topic of writing. The second factor that prevented the development of writing was insufficient description of the language in theoretical terms. The third problem on the way to develop writing was the problem of the writing type selection. Two variants of graphic writing - Hindi or Tibetan - 
were suitable for the language of Dharma. Both were adapted for the use on modern computers. However, the situation was contradictory: writing in Hindi was convenient in terms of ease of learning, it was familiar to all native speakers of the Dharma language but required additional phonetic adaptation of the language; Tibetan writing, which is more in line with the phonetic means of Dharma, is very unfamiliar to the native speakers and, therefore, will cause a lot of difficulties in learning, although they would like to emphasize their historical Tibetan origin. In the end, these contradictions were not solved, thus, writing was not developed. Extra-linguistic factors prevented the development of orthography. Having no written language, Dharma is at the stage of disappearing. It is the reason why the language is not recognized by the Constitution in India. This raises additional concerns for the further life of the language. Yet, for the time being this does not mean that the attempts to develop the system of writing for the Dharma language will not be resumed.

\section{Conclusions}

1. One of the world leading organizations in the field of developing orthographies for unwritten languages is SIL international. Most of modern fundamental theories which the scholars base on when developing new orthographies in the $21^{\text {st }}$ century were members of this organization (K.L. Pike, S. Gudschinsky, M. Cahill, E. Karan, et al.).

2. In modern world practice, three main stages in the development of new orthographies have been recognized as the most important ones: 1) the theoretical stage to study the linguistic features of the language and develop the theoretical version of writing; 2) the field stage when the linguistic "core" of the language gets overgrown with extra-linguistic factors, and doubtful points are clarified by the native speakers, orthography is tested with the native speakers to eliminate problems in the use of the written version of the language; (3) adoption of writing, that is introduction of writing into the indigenous people's practical life (from daily use, creation of educational literature and fiction, websites and mobile applications in the written variant of the language to an exclusively ritual use of the language for the indigenous people's cultural memory preservation).

3. It should be particularly noted that the practices of the $21^{\text {st }}$ century in the field of writing development are always associated with the development of such type of writing, which will be best adapted for its use on modern printing devices (focus on the capacities of the keyboard and available software in the country of the indigenous people's residence) and in the media space (creation of websites, mobile applications). 
4. Successful cases of writing development in the world practice suggest that the linguistic projects of writing that do not take into account extra-linguistic factors (the target audience of the writing system, political context and the people's cultural contacts, the scope of the existing literature) can often fail. Moreover, successful implementation of writing requires its serious support by the absolute majority of native speakers, which can be obtained through constant discussion of all the nuances of writing with the authoritative native speakers. In addition, the joint efforts of the scholars involved in the creation of literature for the indigenous peoples living in the same area can provide a basis for making correct and sustainable decisions in terms of orthography development.

5. An unsuccessful case of writing development designates the important problematic points in the work of the scholars: firstly, lack of social and economic motivation in learning the native language can become an insurmountable factor in the development of orthography; secondly, financing of projects in the field of orthography can serve as a negative factor in the adoption of writing as writing will not be supported by the necessary number of the native speakers' votes.

6. Finally, all linguistic and extra-linguistic rules of SIL international can be used at the stage of testing and approval of writing for the Enets language. Besides, successful solutions and errors in the cases presented can be also taken into account.

\section{References}

Anderson, D., McGowan R., Whistler K. (2005). Recommendation for Creating New Orthographies. In Unicode. Available at: http://www.unicode.org/notes/tn19/

Benton, J.P. (1999). How the Summer Institute of Linguistics has Developed Orthographies for Indigenous Languages in Mexico. In SIL International. Available at: http:/citeseerx.ist.psu.edu/viewdoc/download?doi=10.1.1.628.4359\&rep=rep1\&type=pdf

Berezhnova, M., Pimenova, N.N. (2016). Rost sotsial'no-kul'turnogo raznoobraziia kak rezul'tat mezhetnicheskikh kommunikatsii: iakuty s ozera Essei [The Growth of Socio-Cultural Diversity as a Result of Inter-Ethnic Communications: the Yakuts from Lake Essey]. In Sotsiodinamika [Sociodynamics], 4, 28-40. DOI: 10.7256/24097144.2016.4.18296. Available at: http://e-notabene.ru/pr/article_18296.html

Cahill, M., Karan, E. (2008). Factors in Designing Effective Orthographies for Unwritten Languages. In SIL Electronic Working Papers. Available at: https://www. sil.org/system/files/reapdata/71/22/66/71226648004357014393230040163130285698/ silewp2008_001.pdf 
Cahill, M., Rice K. (eds.) (2014). Developing Orthographies for Unwritten Languages. In SIL international, 265.

Carmen, J. (2010). Orthography Design for Chuxnaban Mixe. In Language Documentation Conservation, 4, 231-253. Available at: https://www.academia. edu/1562642/Orthography_design_for_Chuxnab\%C3\%A1n_Mixe

Fishman, Joshua A. (1977). Advances in the Creation and Revision of Writing Systems. The Hague: Mouton, 491 p.

Gudschinsky, S.C. (1973). A Manual of Literacy for Preliterate Peoples, In SIL international, 180.

Hyslop, G. (2014). Kurtöp Orthography Development in Bhutan, In SIL International Publications in Language Use and Education 6, 2011-230.

Jones, M.C., Mooney, D. (2017). Creating Orthographies for Endangered Languages. Cambridge University Press, 358 p.

Karan, E. (2006). Writing System Development and Reform: a Process. In Grand Forks, North Dakota. Available at: http://emilkirkegaard.dk/lyddanskWP/wp-content/ uploads/2014/11/Writing-system-development-and-reform-A-process.pdf

Karan, E. (2014). The ABD of Orthography Testing: Practical Guidelines. In SIL International Work Papers of the Summer Institute of Linguistics, University of North Dakota Session, 54. Available at: https://arts-sciences.und.edu/summer-institute-oflinguistics/work-papers/_files/docs/2014-karan.pdf

Kistova, A.V., Moskaliuk, M.V., Sertakova, E.A., Dvoretskaia, A.P. (2016). Ispol'zovanie imeni Vasiliia Ivanovicha Surikova v konstruirovanii polozhitel'nogo obraza goroda Krasnoiarska [Using the name of Vasily Ivanovich Surikov in constructing the positive image of the city of Krasnoyarsk]. In NB: Administrativnoe Pravo i Praktika Administrirovaniya [NB: Administrative Law and Administrative Practice], 6, 1-13. DOI: 10.7256/2306-9945.2016.6.20967. Available at: http://enotabene.ru/al/article_20967.html

Koptseva, N.P., Yl'beykina, M.I. (2014). Vizual'naia antropologiia kak aktual'naia oblast' kul'turnykh issledovanii [Visual Anthropology as a Relevant Sphere of Cultural Research]. In Gumanitarnye i sotsial'nye nauki [Humanities and Social Sciences], 2, 133-155.

Koptseva, N.P., Kirko, V.I. (2014). Specificity of Ethnogeny Indigenous Peoples by Central Siberia in the Transition from the Traditional Type of Society to Modern Society. In Life Sci J, 11 (7), 409-413.

Koptseva, N.P., Zamaraeva, J.S., Pimenova, N.N., Kistova, A.V., Seredkina, N.N., Reznikova, K.V. (2016). Regional Peculiarities in Modernization Processes within the 
Territories of Central Siberia. In International Review of Management and Marketing, $6,4,857-865$.

Libakova, N.M., Kolesnik, M.A., Sertakova, E.A. (2017). Issledovatel'skie vozmozhnosti antropologii iskusstva na primere kostoreznykh proizvedenii masterov Sibiri [Research Opportunities in Art Anthropology Based on the Example of the Bone Carving Works of Siberian Masters], In Sibirskii antropologicheskii zhurnal [Siberian Anthropological Journal], 1 (1), 22-34.

Libakova, N.M., Sertakova, E.A. (2018). Korennoe zdravookhranenie - tekushchee sostoianie i perspektivy (na materiale Krasnoiarskogo kraia) [Indigenous Health Care Current Condition and Prospectives (Based on Krasnoyarsk Territory Materials)]. In Sibirskii antropologicheskii zhurnal [Siberian Anthropological Journal], 2, 1, 6-19.

McBride, J.T. (2009). Orthography and Ideology: Examining the Development of Kaw Writing. In D. Rosenblum \& C. Meeker (Eds.), Santa Barbara Papers in Linguistics, 20, Proceedings from the Twelfth Workshop on American Indigenous Languages, 30-45. Available at: http://www.linguistics.ucsb.edu/sites/secure.lsit.ucsb. edu.ling.d7/files/sitefiles/research/papers/20/SBPL20_McBride.pdf

Official Web-Site of MIROMAA. Aboriginal Language and Technology Centre. Available at: http://www.miromaa.org.au/

Official Web-Site of SIL International. Available at: http://www.sil.org

Oko, Ch.M.W. (2018). Orthography Development for Darma (The Case That Wasn't). In Language Documentation and Conservation, 12, 15-46. Available at: https://scholarspace.manoa.hawaii.edu/bitstream/10125/24761/1/oko.pdf

Pike, K.L. (1947). Phonemics: A Technique for Reducing Languages to Writing. University of Michigan Press, $254 \mathrm{p}$.

Pimenova, N.N. (2018). Sovremennaia filosofskaia pozitsiia po voprosu mekhanizmov sotsiokul'turnykh izmenenii [Modern Philosophical Position on the Mechanisms of Socio-Cultural Changes]. In Sibirskii antropologicheskii zhurnal [Siberian Anthropological Journal], 2, 2, 47-69.

Reznikova, K.V., Zamaraeva, Yu.S., Sergeeva, N.A. (2018). The Sociocultural Problems of Teaching the Entsy Language. In Journal of Siberian Federal University. Humanities \& Social Sciences, 7, 11, 1137-1150. Available at: http://elib.sfu-kras.ru/ bitstream/handle/2311/71765/Reznikova.pdf;jsessionid=42E3486035EBD96346C 685E696957DB0?sequence $=1$

Reznikova, K.V., Seredkina, N.N., Koptseva, N.P., Zamaraeva, J.S. (2016). Regional'naia spetsifika sotsial'nykh tsennostei i ikh vliianie na protsessy modernizatsii 
territorii Tsentral'noi Sibiri (na materiale issledovanii Krasnoiarskogo kraia) [Regional Specifics of Social Values and Their Impact on Central Siberian Territories Modernization (Based on Research of Krasnoyarsk Region)]. In Ekonomichnii chasopis - XXI [Economic Annals - XXI], 7-8 (160), 92-95.

Robinson, C., Gadelii, C. (2003). Writing Unwritten Languages - a Guide to the Process: Working Paper. In United Nations Educational, Scientific and Cultural Organizations. Available at: http://unesdoc.unesco.org/images/0022/002264/226475e.pdf

Sertakova, E.A. (2018). Filosofskie osnovaniia sovremennoi urbanisticheskoi antropologii [Philosophical Foundation of Modern Urban Anthropology]. In Sibirskii antropologicheskii zhurnal [Siberian Anthropological Journal], 2, 2, 70-86.

Simons, G.F., Fennig, C.D. (eds.) (2018). Ethnologue: Languages of the World, Twenty-First Edition. Dallas, Texas: SIL International. Available at (online version): http://www.ethnologue.com

Smalley, W. (1964). How Shall I Write This Language? Orthography Studies: Articles on New Writing Systems. In Helps for Translators 6. London: United Bible Societies, 31-52.

Snider, K. (2014). On Establishing Underlying Tonal Contrast. In Language Documentation \& Conservation, 8, 707-737.

Townsend, W.C. (1961). Cakchiquel Grammar. In Summer Institute of Linguistics of the University of Oklahoma. Linguistic Series, 5, 1-79.

Weth, C., Juffermans, K. (eds.) (2018). The Tyranny of Writing. Ideologies of Written World. In Bloomsbury Academic. Series Advances in Sociolinguistics, 240.

Zamaraeva, Yu.S., Reznikova, K.V., Pimenova, N.N. (2017). Istoriia antropologicheskikh issledovanii korennykh narodov Sibiri [The History of Anthropological Studies on the Indigenous Peoples of Siberia]. In Sibirskii antropologicheskii zhurnal [Siberian Anthropological Journal], 1 (1), 6-21. 


\title{
Мировой опыт создания письменности \\ для ранее бесписьменных культур
}

\author{
А.А. Ситникова \\ Сибирский федеральный университет \\ Россия, 660041, Красноярск, пр. Свободныий, 79
}

B статье рассмотрены зарубежные научные практики по созданию орфографий для бесписьменных языков с иелью поиска качественного и эффективного алгоритма для утверждения и развития энецккой письменности. В обзоре современных зарубежных исследований доминирует анализ научных публикащий, выпущенных учеными SIL international - наиболее опьтной и авторитетной организации в этой области. В первой части статьи представлено описание признанного наиболее перспективным в начале XXI века алгоритма по созданию письменностей для языков коренных народов - выделены этапы, принципы и научные установки, перечислены лингвистические и нелингвистические вызовы, возникающие при разработке письменности. Во второй части статьи рассмотрены конкретные случаи: а) успешного создания письменности учеными SIL для мексиканских языков, в частности для микстекского языка; б) безуспешной на сегоднямний день попьтки создания письменности для народа дарма, проживающего на территории Непала на границе с Индией. По итогам сделаны выводы о том, какие современные методики в области создания орфографий могут быть использованы для создания письменности энецкого языка.

Ключевые слова: орфография для бесписьменных языков, бесписьменные языки, кейсстади создания письменности в XXI веке, энецкий/энский язык.

Исследование выполнено при поддержке Красноярского краевого фонда науки в рамках реализачии проекта «Разработка научно-методического обеспечения сохранения уникального культурного наследия для кетской и энецкой этнокультурных групп коренных малочисленных народов Севера, Сибири и Дальнего Востока, прожсивающих на территории Красноярского края».

Научная специильность: 24.00.00 - культурология. 